\title{
STRUKTUR MODAL TERHADAP ECONOMIC VALUE ADDED PADA PT PRIMARINDO ASIA INFRASTRUCTURE TBK TAHUN 2001-2015
}

\author{
Muhammad Husain Muthahhari \\ Universitas Pendidikan Indonesia \\ muhammad.husain@student.upi.edu \\ Imas Purnamasari \\ Universitas Pendidikan Indonesia \\ imaspurnamasari@upi.edu \\ Sulastri \\ Universitas Pendidikan Indonesia \\ sulastri@upi.edu
}

\begin{abstract}
ABSTRAK
Tujuan - Penelitian ini dilaksanakan untuk melihat gambaran struktur modal dan economic value added. Desain/metodologi/pendekatan -Metode penelitian ini menggunakan metode verifikatif . Objek dalam penelitian ini yaitu PT Primarindo Asia Infrastructure Tbk. Teknik pengumpulan data dengan time series. Teknik analisis data dengan menggunakan teknik analisis regresi sederhana yaitu dengan bantuan SPSS 20 for windows.

Temuan - Berdsarkan hasil penelitian menggunakan analisis verifikatif, didapatkan hasil bahwa struktur modal tidak berpengaruh positif terhadap economic value added yang berarti jika terjadi perubahan struktur modal akan berpengaruh dengan meningkatnya economic value added

Orisinalitas/nilai - Penelitian ini memberikan dasar untuk memahami isu-isu gambaran struktur modal dan Economic value added. Perbedaan penelitian ini dengan penelitian sebelumnya adalah terletak pada objek yang merupakan perusahaan dalam industri manufaktur yaitu PT Primarindo Asia Infrastuktur Tbk dengan variabel yang diteliti yaitu struktur modal, dan economic value added, serta menggunakan teori atau referensi yang berbeda dengan peneliti sebelumnya. Hasil dari penelitian ini bahwa struktur modal yang di hidung menggunakan debt to equity ratio memiliki hasil negative .
\end{abstract}

Kata Kunci : struktur modal, economic value added

Tipe Artikel : Research Paper

\section{ABSTRACT}

Purpose - This study was conducted to look at the capital structure and economic value added

Design / methodology / approach -The method of this research using and verification.. The object of this research is PT Primarindo Asia Infrastructure Tbk. Data collection techniques with time series. Data analysis techniques using multiple analysis techniques that is with the help of SPSS 20 for windows.

Findings - Based on the results of research using verifikatif analysis, obtained the result that the capital structure does not have a positive effect on economic value added which means if there is a change in capital structure will affect with the increase of economic value added

Originality / value - This research provides a basis for understanding the issues of capital structure overview and Economic value added. The difference of this research with the previous research is located on the object which is the company in the manufacturing industry that is PT Primarindo Asia Infrastructure Tbk with the variables studied are capital structure, and economic value added, and using theory or reference different from previous researchers. The results of this study that the structure of the capital in the nose using debt to equity ratio has a negative result

Keywords: capital structure, economic value added

Kinerja perusahaan dapat diukur menggunakan berbagai metode. kinerja keuangan 
perusahaan sangat ditentukan oleh sistem pengendalian manajemen yang terdiri dari struktur dan proses (Purnamasari, 2009) Salah satu metode yang biasanya digunakan adalah profitabilitas sebagai ukuran efisiensi dari kinerja perusahaan secara keseluruhan (Niresh \& Velnampy, 2014). Selama ini alat yang digunakan untuk mengukur kinerja perusahaan adalah analisis rasio keuangan, yaitu Rasio likuiditas, Rasio leverage, Rasio aktivitas, Rasio profitabilitas, Rasio pertumbuhan. Namun, rasio keuangan tersebut mempunyai kelemahan. Kelemahan utamanya adalah bahwa rasio tersebut mengabaikan adanya biaya modal, sehingga sulit untuk mengetahui apakah perusahaan telah menciptakan nilai atau tidak. Mengingat keterbatasan analisis rasio sebagai alat pengukur kinerja keuangan maka ada pendekatan konsep baru yang disebut Economic Value Added (EVA) Ningsih dan Suwardi (2015) mengungkapkan bahwa penggunaan ukuran kinerja perusahaan yang mendasar pada analisis rasio keuangan sebagai alat pengukur akuntansi konvensional, seperti rasio profitabilitas memiliki kelemahan utama yaitu mengabaikan adanya biaya modal sehingga sulit untuk mengetahui apakah suatu perusahaan telah berhasil menciptakan nilai perusahaan atau tidak. Mendukung penelitian (Fitriani \& Purnamasari, 2015) bahwa profitabilitas tidak berpengaruh terhadap struktur modal Untuk mengatasi kelemahan tersebut dikembangkan suatu pendekatan baru dalam menilai kinerja suatu perusahaan, yaitu Economic Value Added (EVA). Perusahaan lebih baik menerapkan EVA sebagai alat ukur kinerja perusahaan dibandingkan dengan profitabilitas, EVA dianggap lebih baik karena memperhitungkan biaya ekuitas (Kaunang, 2013)..Jika nilai EVA > 0 berarti bahwa manajemen perusahaan mampu menciptakan nilai ekonomi bagi pemegang saham, dan menunjukkan kinerja keuangan perusahaan juga baik (Arisanti \& Bayangkara, 2016).

Menurut Hafsah dan Sri Utari Sari (2015) pendekatan dengan metode EVA dianggap lebih akurat dan komperehensif dibanding dengan pendekatan konvensional terdahulu yang tidak menggambarkan kondisi keuangan perusahaan sebenarnya, karena dengan mengaplikasikan metode EVA, para manajer akan memilih investasi yang dapat memaksimumkan tingkat pengembalian dan meminimumkan tingkat biaya modal, sehingga nilai perusahaan dapat dicapai secara optimal. Dengan demikian, menunjukan bahwa EVA lebih baik digunakan untuk mengukur nilai perusahaan dari pada profitabilitas, karena tujuan utama dari semua bisnis adalah nilai perusahaan itu sendiri.
Sebagai perusahaan modern dan go public. PT Primarindo Asia Infrastructure Tbk. memiliki visi "Menjadi pemimpin dalam industri sepatu di Indonesia". Pada salah satu moto perusahaan mempunyai proses produksi yang paling efisien, serta menjadi mitra usaha terpercaya dalam menghadapi tantangan saat ini dan di masa depan. Permasalahannya sebagai perusahaan yang besar, nilai EVA dari PT. Primarindo ini masih berfluktuatif nilainya. Pada Tahun 2001-2008, nilai EVA perusahaan ini memiliki nilai negatif. Hal ini sebagai imbas dari krisis moneter yang menimpa perekonomian Indonesia. Baru pada Tahun 2009, PT. Primarindo Asia Infrastructure Tbk mampu meningkatkan nilai EVA menjadi positif sampai pada angka 12,689,367,444. Namun, pada terakhir yaitu Tahun 2015, nilai EVA perusahaan ini mengalami penurunan yang cukup signifikan, dari 14,763,985,714 pada Tahun 2014 menjadi 6,479,787,394 pada Tahun 2015 (annual reports PT. Primarindo Asia Infrastucture Tbk, 2016).

Penurunan nilai EVA PT Primarindo Asia Infrastructure Tbk menjadi kondisi yang sangat mengkhawatirkan, karena sebagai perusahaan yang sudah go public, para pemegang saham akan menarik investasi mereka dan mungkin banyak karyawan yang terkena Pemutusan Hubungan Kerja (PHK).

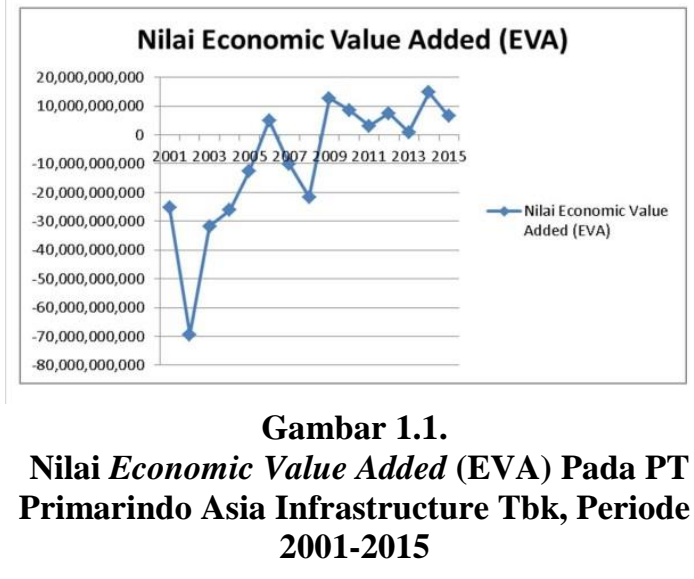

Berdasarkan Gambar 1.1 Nilai EVA PT. Primarindo Asia Infastucture Tbk dapat dilihat mengalami kenaikan menjadi bernilai positif semenjak Tahun 2009, Namun nilainya terus berfluktuatif sampai pada Tahun 2015. Pada Tahun 2015 nilainya mengalami penurunan dibandingkan Tahun 2014. Penurunan nilai EVA PT. Primarindo Asia Infastucture Tbk merupakan suatu permasalahan yang harus segera diatasi oleh manajemen PT. Primarindo Asia Infastucture Tbk, karena penurunan EVA berpengaruh pada tingkat kepercayaan investor. Berdasarkan annual report Primarindo Asia Infastucture Tbk, penurunan kinerja keuangan ini disebabkan oleh 
berbagai faktor, diantanya pengelolaan modal yang kurang tepat dan kurang lakunya produk yang dihasilkan di pasaran.

Pentingnya pengukuran kinerja keuangan dengan metode EVA adalah untuk mengukur nilai suatu perusahaan dalam menghasilkan dana yang diinvestasikan ke perusahaan. Jika perusahaan memiliki EVA negatif, itu berarti perusahaan tidak menghasilkan nilai dari dana yang diinvestasikan ke dalam bisnis. Sebaliknya, EVA positif menunjukkan perusahaan memproduksi nilai dari dana yang diinvestasikan di dalamnya (Daru, 2016) Perusahaan dapat menggunakan EVA sebagai ukuran kinerja untuk pilihan strategi perusahaan seperti merger dan akuisisi. EVA juga lebih baik dalam mengukur dan memandu penciptaan nilai perusahaan (Khan et all, 2016). mengamati bahwa EVA adalah ukuran sebenarnya dari kinerja dan ekonomi perusahaan.

Leepsa dan Mishra (2016) menyimpulkan bahwa faktor-faktor yang akan mempengaruhi EVA adalah sebagai berikut : Profitabilitas, struktur modal, lama usaha, ukuran perusahaan, lingkungan investasi dan ukuran kinerja pasar. Lin dan Zhilin (2008) menyimpulkan bahwa faktor-faktor yang mempengaurhi EVA adalah struktur modal, profitabilitas, ukuran perusahaan, pertumbuhan, kemampuan manajemen, dan Return on Equity (ROE) memiliki pengaruh positif terhadap EVA.

Pembahasan mengenai pengaruh struktur modal terhadap Economic Value Added perusahaan masih jarang dilakukan. Penelitian yang dilakukan Suwito, (2002) mengenai hubungan struktur modal dengan Economic Value Added menunjukkan bahwa terdapat korelasi yang signifikan antara perubahan proporsi utang dan modal saham perusahaan dengan perubahan EVA.

Hasil penelitiannya menunjukkan bahwa setiap penambahan utang dan modal saham di dalam struktur modal perusahaan akan diikuti pula dengan penurunan EVA. Hal ini berbeda dengan hasil penelitian yang dilakukan (Anshari, 2004) yang juga melakukan penelitian mengenai hubungan struktur modal dengan economic value added perusahaan. Anshari berkesimpulan bahwa tidak terdapat korelasi signifikan antara perubahan proporsi utang ataupun modal saham dengan perubahan EVA. Penelitiannya menunjukkan bahwa meskipun proporsi utang perusahaan terus meningkat, bukan berarti EVA perusahaan juga akan turun. Nugraha (2013) menyimpulkan bahwa struktur modal yang diukur dengan DER dan berpengaruh signifikan terhadap nilai EVA.

\section{KAJIAN PUSTAKA}

Salah satu metode baru dalam menilai kinerja perusahaan yang mencerminkan nilai perusahaan adalah Economic Value Added (EVA), yang di Indonesia dikenal dengan istilah Nilai Tambah Ekonomi (NITAMI). Nilai tambah ekonomi atau EVA pertama kali diperkenalkan oleh Sterwart (dalam A.Sakir, 2009:151) yang mendefenisikan EVA sebagai berikut: "EVA adalah mengukur income residual dikurangi biaya modal dari hasil laba opersai dalam bisnis". EVA akan meningkat seandainya laba operasi dapat tumbuh tanpa meningkatnya biaya modal.

Jika laba baru diinvestasikan dalam proyek yang ada atau semua proyek yang memperoleh laba lebih daripada biaya modal keseluruhan, dengan kata lain dapat dikatakan bahwa EVA merupakan cara mengukur sisa laba yang dihasilkan perusahaan dengan mengurangi laba opersai dengan biaya modal.

Dalam hal ini, EVA akan meningkat jika pertumbuhan atau peningkatan laba operasi tidak diikuti oleh adanya peningkatan modal. Menurut (A.Sakir, 2009) EVA adalah suatu cara untuk mengukur laba riil yang merupakan kunci nyata dalam menciptakan kemakmuran. EVA merupakan suatu konsep baru untuk menilai kinerja perusahaan independen dan sekaligus dapat mengukur kemampuan untuk meningkatkan laba dan pertumbuhan. Model ini dapat juga digunakan untuk menilai tingkat keberhasilan dari suatu kegiatan dari sisi kepentingan dan harapan penyandang dana (pemegang saham dan kreditur) yang selalu menuntut eksekutif perusahaan agar mampu menghasilkan nilai tambah dari kegiatan perusahaan.

EVA dapat digunakan untuk mengidentifikasi kegiatan atau proyek yang memberikan pengembalian lebih tinggi dari pada biaya modalnya. Kegiatan atau proyek yang memberikan nilai sekarang dari total EVA yang positif menunjukkan bahwa proyek tersebut menciptakan nilai perusahaan dan dengan demikian sebaiknya diambil. Sebaliknya, kegiatan atau proyek tersebut tidak menguntungkan dan tidak perlu diambil. Penggunaan EVA dalam mengevaluasi proyek akan mendorong para manajer untuk selalu melakukan evaluasi atas tingkat resiko proyek yang bersangkutan. Dengan EVA, para manajer harus selalu membandingkan tingkat pengembalian proyek dengan tingkat biaya modal yang mencerminkan tingkat risiko proyek tersebut.

Menurut Siddharta Utama (1997) oleh penilaian EVA dapat dinyatakan sebagai berikut: a)Apabila EVA > 0, berarti nilai EVA positif yang menunjukkan telah terjadi proses nilai tambah pada perusahaan. b) Apabila EVA $=0$ menunjukkan posisi impas atau Break Event 
Point. c)Apabila EVA < 0, yang berarti EVA negatif menunjukkan tidak terjadi proses nilai tambah.

Perhitungan EVA digunakan oleh perusahaan untuk mengukur kinerja perusahaan yaitu untuk menghitung economic profit yang dihasilkan oleh perusahaan setiap tahunnya. Dari hasil perhitungan EVA dapat diketahui apakah manajemen perusahaan dapat meningkatkan nilai perusahaan yang berdampak pada nilai pengembalian pemegang saham. Dalam menghitung EVA digunakan rumus adjusted net operating income after tax dikurangi dengan tingkat biaya modal yang telah dikalikan dengan total modal (capital charges).

Atau dengan cara lain, cara mencari EVA yaitu return on net asset dikurangi dengan tingkat biaya modal dikalikan dengan total modal. Adapun langkah langkah yang harus dilakukan adalah menghitung net operating income after tax (NOPAT), Return on net asset, invested capital, cost of equty, cost of debt, dan weighted cost of capital. Adapun return on net asset dapat di hitung dari penjualan dibagi dengan net asset. Adapun rumus, emgitung EVA sebagai berikut :

\section{EVA $=$ NOPAT $-($ WACC $\times$ Invested Capital $)$}

Manajemen Keuangan merupakan manajemen yang mengelola masalah keuangan perusahaan, dan manajemen keuangan faktor yang terpenting dalam keberhasilan suatu perusahaan. Peranan manajamen keuangan dalam suatu perusahaan untuk mengendalikan segala aktivitas yang terjadi, baik secara internal maupun eksternal. Brigham dan Houston (2002:31) menyatakan bahwa manajemen keuangan adalah seri dan ilmu, untuk mengatur uang yang meliputi proses, intitusi, pasar, dan instrument yang terlibat dengan masalah transfer uang diantara individu, bisnis, dan pemerintah

Biasanya penggunaan rasio solvabilitas atau leverage disesuaikan dengan tujuan perusahaan. Artinya perusahaan dapat menggunakan rasio leverage secara keseluruhan atau sebagian dari masing-masing jenis rasio solvabilitas yang ada. Dalam praktiknya, terdapat beberapa jenis rasio solvabilitas yang sering digunakan perusahaan. Adapun jenis-jenis indikator yang ada dalam rasio solvabilitas antara lain: a) Debt to Asset Ratio (DAR) b) Debt to Equity Ratio (DER) c) Long term Debt to Equity Ratio (LDER) d) Tangible assets debt coverage e) Current liabilites to net worth f) Times Interest Earned (TIE) g) Fixed charge coverage h) Equity to Ttotal Assets Ratio (EAR)

Menurut Kasmir (2012:158), rasio ini berguna untuk mengetahui jumlah dana yang disediakan peminjam (kreditor) dengan pemilik perusahaan. Rasio ini juga berfungsi untuk mengetahui setiap rupiah modal sendiri yang dijadikan untuk jaminan utang.. Menurut Brigham dan Houston (2001:58) Debt to Equity Ratio (DER) merupakan perbandingan antara total hutang dengan modal sendiri. Rasio ini menunjukkan kemampuan modal sendiri perusahaan untuk memenuhi kewajibannya. (Dwirachma \& Imas, 2014) Hasil penelitian menunjukkan bahwa Struktur Modal berpengaruh positifterhadap Nilai Perusahaan Perusahaan Asuransi yang Listing di Bursa EfekIndonesia periode 2009-2012 Sementara penelitian terdahulu mengenai debt to equity ratio terhadap lama menunjukan Leverage (DER) berpengaruh terhadap pertumbuhan laba (Muslimah, Purnamasari, \& Andari, 2016)

Setelah ditunda sejak akhir 1985, pemerintah Indonesia secara resmi menerapkan ketentuan pembatasan rasio utang terhadap modal (Debt to Equity Ratio / DER) 4:1 lebih longgar dari patokan terdahulu 3:1. Kebijakan itu diamanatkan dalam Peraturan Menteri Keuangan No. 169/PMK.010/2015 tentang Penentuan Besarnya Perbandingan Antara Utang dan Modal Perusahaan Untuk Keperluan Penghitungan Pajak Penghasilan yang ditetapkan dan diundangkan pada 9 September 2015.

Dalam pasal 1 ayat (1) PMK tesebut dinyatakan untuk keperluan penghitungan Pajak Penghasilan (PPh) ditetapkan besarnya perbandingan antara utang dan modal bagi Wajib Pajak (WP) badan yang didirikan atau bertempat kedudukan di Indonesia yang modalnya terbagi atas saham-saham."Besarnya perbandingan antara utang dan modal sebagaimana dimaksud dalam Pasal 1 ayat (1) ditetapkan paling tinggi sebesar empat dibanding satu (4: 1)," bunyi pasal 2 aturan tersebut. Dengan batasan tersebut di tentukan $80 \%$ utang dan $20 \%$ modal perusahaan, besaran utang lebih dari $80 \%$ harus membayar pajak.

Berdasarkan data dari laporan tahunan PT. Primarindo, dapat diketahui bahwa total hutang perusahaan pada Tahun 2016 mengalami penurunan dari 301,57 miliar (Tahun 2015) menjadi 189, 22 miliar (Tahun 2016). Adapun struktur modal Perseroan pada tahun 2016 terdiri dari hutang sebesar Rp. 189,22 miliar dan ekuitas sebesar minus Rp. 97,18 miliar. Rasio hutang terhadap ekuitas bersih Perseroan adalah sebesar minus $95,87 \%$ pada tahun 2016 dan minus $56,98 \%$ pada tahun 2015. Dengan demikian, pada Tahun 2015 berdasarkan pasal 1 ayat 1 tentang pembayaran wajib pajak, PT. Primarindo tidak terkana wajib pajak atas utang yang melebihi $80 \%$, sedangkan pada Tahun 2016 PT. 
Primarindo terkana wajib pajak atas rasio utang atas modal yang lebih dari $80 \%$.

Adapun rumus untuk menghitung Debt to Equity Ratio (DER) menurut (Kasmir (2008:158) adalah sebagai berikut:

Debe to Equivy Retio $=\frac{\text { Total Huterng }}{\text { Modal }} \times 100 \%$

\section{METODE PENELITIAN}

Penelitian ini dilakukan untuk mengetahui struktur modal terhadap economic value added. Variabel bebas yang terdapat pada penelitian ini yaitu struktu rmodal Sedangkan variabel terikat yaitu economic value added.

Objek/unit pada penelitian ini PT Primarindo Asia Infrastuktur Tbk. Penelitian ini menggunakan data keuangan perusahaan dari tahun 2001-2015 dengan menggunakan penelitian populasi. Sedangkan teknik analisis data yang dilakukan adalah analisis verifikatif. Analisis data verifikatif menggunakan analisis regresi linear sederhana dengan bantuan software SPSS 20 for windows.

\section{HASIL PENELITIAN DAN PEMBAHASAN}

Penelitian ini terdiri dari variabel independen yaitu debt to equity ratio dengan variabel dependen economic value added. Untuk mengetahui pengaruh dari variabel independen tersebut terhadap variabel dependen, maka dilakukan analisis regresi sederhana. Persamaan regresi untuk penelitian ini adalah sebagai berikut:

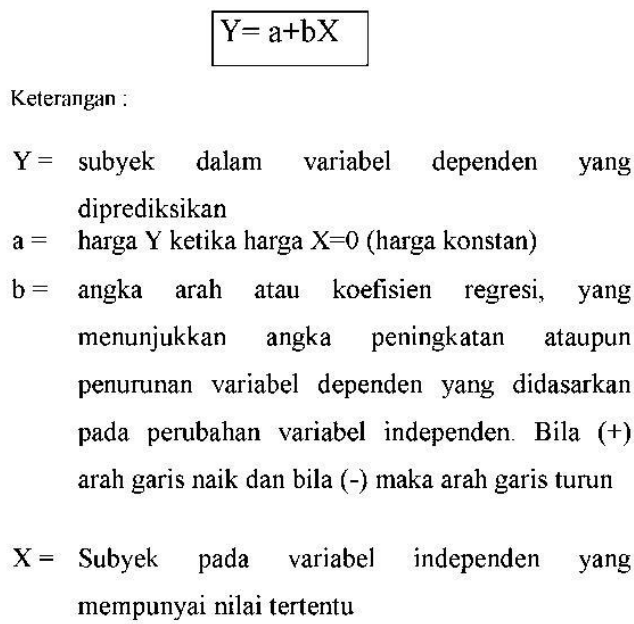$$
\mathrm{Y}=\mathrm{a}+\mathrm{bX}
$$

Adapun untuk perhitungan regresi linear multipel ini menggunakan SPSS 20, dengan hasil sebagai berikut:

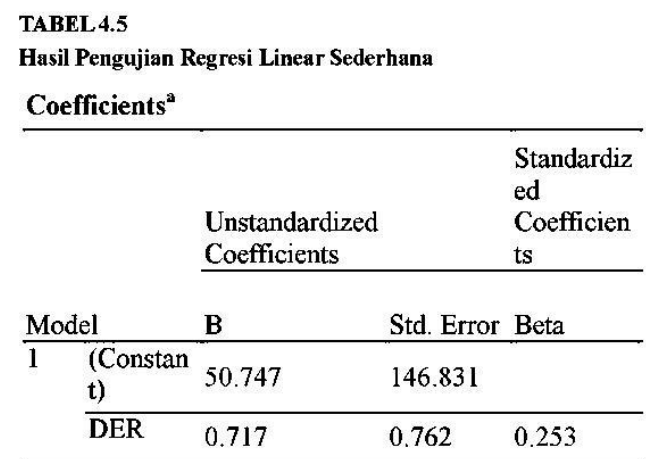

a. Dependent Variable: EVA

Sumber: Hasil pengujian regresi linear sederhana menggunakan SPSS 20.

Berdasarkan Tabel 4.5 hasil pengujian analisis regresi sederhana di atas diperoleh nilai konstanta sebesar 50,747 koefisien DER sebesar 0.717 Persamaan regresi yang dapat dibentuk dari nilainilai tersebut adalah sebagai berikut:

$\mathrm{Y}=50,747+0.717 \mathrm{X}$

Berikut adalah interpretasi dari persamaan regresi linear multipel yang telah disajikan di atas: a) EVA, variabel dependen (Y) b) Konstanta (a) = 50,747 Tanpa adanya pengaruh dari variabel struktur modal atau variabel tidak ada perubahan, maka variabel economic value added (Y) memiliki nilai 50,747 c) Koefisien regresi $b=0.717$ debt to equity ratio Arti dari nilai tersebut adalah debt to equity ratio memiliki hubungan arah yang positif (searah) dengan economic value added. Setiap peningkatan debt to equity ratio sebesar satu persen maka pun akan meningkat sebesar 0.717 kali.

Uji keberartian regresi yang dikenal dengan uji $\mathrm{F}$ dimaksudkan untuk mengetahui apakah regresi yang didapatkan dari hasil penelitian memiliki arti untuk membuat kesimpulan mengenai hubungan sejumlah peubah yang diteliti. Uji $F$ dilakukan dengan menguji hipotesis di bawah ini:

$\mathrm{H}_{0}$ : regresi tidak berarti

$\mathrm{H}_{1}$ : regresi berarti

Dengan kriteia pengujian

a. Jika $\mathrm{F}$ hitung $>\mathrm{F}$ tabel, maka $\mathrm{H}_{0}$ ditolak

b. Jika $\mathrm{F}$ hitung $\leq \mathrm{F}$ tabel, maka $\mathrm{H}_{0}$ diterima

Berikut akan disajikan tabel ANOVA hasil pengujian menggunakan SPSS 20 untuk mengetahui nilai $\mathrm{F}$ hitung: 


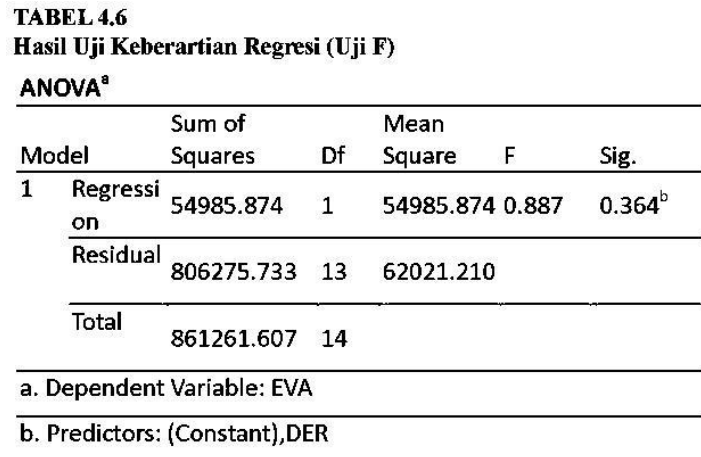

\section{Sumber: Hasil Uji F menggunakan SPSS 20}

Sesuai dengan kriteria penujian, maka F hitung yang telah diperoleh akan dibandingkan dengan nilai $F$ yang ada dalam tabel distribusi $F$. Berdasarkan Tabel 4.6 di atas, $\mathrm{F}$ hitung bernilai 0.887 sedangkan $\mathrm{F}$ tabel dengan taraf signifikansi $0,05, \mathrm{k}=1, \mathrm{n}=15$, dK pembilang $=\mathrm{k}-1=2$, dan $\mathrm{dK}$ penyebut $=\mathrm{n}-\mathrm{k}-1=15-1-1=13$ bernilai 3,805 Maka dapat disimpulkan bahwa F hitung > $\mathrm{F}$ tabel yang berarti $\mathrm{H}_{0}$ ditolak dan model regresi yang digunakan berarti.

Uji $t$ atau uji keberartian koefisien regresi dilakukan untuk menguji pengaruh setiap variabel independen terhadap variabel dependen. Berdasarkan output SPSS 20, uji t dari variabel modal kerja terhadap profitabilitas ditunjukkan dalam tabel di bawah ini:

TABEL 4.7

Hasil Uji Keberartian Koefisien Regresi (Uji t)

Coefficients $^{a}$

\begin{tabular}{lll}
\hline $\begin{array}{l}\text { Mode } \\
\text { I }\end{array}$ & T & Sig. \\
\hline $1 \quad$ (Constant) & 0.346 & 0.735 \\
& 0.942 & 0.364 \\
\hline DER & & \\
\hline Coefficients $^{2}$ & & \\
\hline
\end{tabular}

Sumber: Hasil uji t menggunakan SPSS 20.

Setelah perumusan hipotesis, uji $t$ dilakukan dengan membandingkan $t$ hitung dengan $\mathrm{t}$ tabel dalam taraf signifikansi 0,05 dan $\mathrm{db}=\mathrm{n}-\mathrm{k}-1=15-1-1=13$. Adapun kriteria pengambilan keputusannya adalah sebagai berikut:

Hipotesis yang akan di uji adalah sebagai berikut: $\mathrm{H} 0: \beta=0, \quad$ tidak terdapat pengaruh struktur modal terhadap Economic Value Added.

H1 : $\beta \neq 0$, terdapat struktur modal terhadap Economic Value Added.

Selanjutnya, untuk melihat $\mathrm{t}$ tabel harus digunakan distribusi student $\mathrm{t}$ dengan $\mathrm{dk}=(\mathrm{n}-2)$, dengan uji pihak kanan dan pihak kiri (uji 2 pihak), dengan taraf signifikansi 0,05. Adapun kriteria pengambilan keputusannya adalah sebagai berikut:

Jika thitung $>\mathrm{t}$ tabel maka $\mathrm{H}_{0}$ ditolak

Jika t hitung $\leq \mathrm{t}$ tabel maka $\mathrm{H}_{0}$ diterima

Berikut ini akan disajikan tabel perbandingan antara $\mathrm{t}$ hitung dan $\mathrm{t}$ tabel dari setiap variabel:

\section{TABEL 4.8}

Perbandingan T Hitung Dan T Tabel

No. Variabel thitung t tabel Signifikansi Keputusan

\begin{tabular}{llllll}
\hline & (DER) & & & & \\
1. & & 0.942 & 2,17 & 0.364 & $\mathrm{H}_{0}$ diterima
\end{tabular}

Berdasarkan Tabel 4.8 tentang signifikansi setiap variabel independen dari penelitian ini, dapat diketahui bahwa variabel Struktur Modal tidak berpengaruh terhadap Economic Value Added. Penelitian ini dikukung olehpenelitihan terdahulu tentang struktur permodalan dan struktur modal kerja terhadap profitabilitas melalui uji $\mathrm{F}$ dan $\mathrm{T}$-test menunjukkan bahwa struktur modal berpengaruh negatif terhadap profitabilitas secara signifikan (Dintha \& Surachim, 2016).

Berdasarkan hasil kajian mengenai Pengaruh Struktur Modal terhadap Economic Value Added pada PT. Primarindo Asia Infrastuktur Tbk Tahun 2001-2015, maka dihasilkan temuan sebaga berikut: a) Economic Value Added dapat ditingkatkan jika perusahaan mengelola struktur modal dengan cara yang lebih efisien. Terdapat hubungan korelasi yang kuat dan bersifat negative artinya bila perputaran struktur modal naik maka perolehan economic value added pun naik. Rasio ini dapat digunakan untuk mengukur kinerja sebuah perusahaan manufaktur yang ada di Indonesia, hal ini sesuai dengan konsep yang dikemukakan oleh Hafsah dan Sri Sutra Sari (2015). b) Perusahaanperusahaan manufaktur memiliki kinerja yang baik yaitu perusahaan yang memeroleh keuntungan. Kebutuhan modal kerja berkaitan erat dengan tingkat profitabilitas perusahaan, semakin tinggi modal kerja maka semakin tinggi keuntungan yang diperoleh yang diukur dengan Economic Value Added, hal ini sesuai dengan konsep yang dijelaskan oleh Nufazil Altaf (2016) dan Lin \& Qiao Zhilin (2008).

Berdasarkan temuan-temuan tersebut penulis memiliki keyakinan bahwa hasil penelitian ini memiliki kontribusi ilmiah terhadap pengembangan ilmu manajemen keuangan, khususnya dalam konsep economic value added untuk mengetahui tingkat keuntungan yang diperoleh perusahaan. 
Selain menghasilkan temuan secara teoritis, penelitian ini menghasilkan temuan secara empiris. Temuan yang bersifat empiris pada penelitian ini yaitu: a) Hasil empiris Pengaruh Struktur Modal terhadap economic value added pada PT. Primarindo Asia Insfrastuktur Tbk Tahun bahwa rasio EVA cenderung mengalami penurunan PT. Primarindo Asia Infrastuktur Tbk mengalami penurunan terus menerus dan pada tahun 2015 terjadi penurunan secara drastis menjadi $6,479,787,394$ dari tahun 2014 yang mencapai $14,763,985,714$.

Economic value added merupakan salah satu alat ukur yang penting untuk menilai kinerja sebuah perusahaan, karena semakin tinggi EVA menandakan semakin baik kinerja suatu perusahaan terutama dalam hal laba dan modal. Jika dilihat dari tingkat EVA PT. Primarindo Asia Infrastuktur Tbk, tercatat sedang tidak dalam kondisi yang baik terlihat dari banyaknya penurunan yang terjadi hingga nilai dari EVA yang mencapai nilai negatif. dan hasil EVA PT. Primarindo Asia Infrastuktur Tbk $>0$, berarti nilai EVA positif yang menunjukkan telah terjadi proses nilai tambah pada perusahaan. b) Keterkaitan Struktur Modal dengan economic value added .Variabel independen tidak berpengaruh terhadap variabel dependen, yang berarti struktur modal yang di ukur oleh DER sebagai berikut: Koefisien regresi $b=0.717 \mathrm{debt}$ to equity ratio Arti dari nilai tersebut adalah debt to equity ratio memiliki hubungan arah yang negatif dengan economic value added. Setiap peningkatan debt to equity ratio sebesar satu persen maka economic value added pun akan meningkat sebesar $0.717 \mathrm{kali}$.

Adanya penelitian ini diharapkan dapat membantu peneliti berikutnya dalam melakukan penelitian mengenai struktur modal dan economic value added dengan menggunkan indikator yang berbeda dari sumber teori yang lebih beragam, dan terhadap objek yang berbeda, karena masih banyaknya keterbatasan dalam penelitian ini, khususnya yang berkaitan dengan metode penelitian dan teknik pengumpulan data.

\section{DAFTAR PUSTAKA}

A.Sakir. (2009). Pengaruh Economic Value Added (EVA)terhadap harga saham perusahaan yang terdaftar di Jakarta Islamic Index Bursa Efek Indonesia, Ekonomi dan Bisnis. Ekonomi Dan Bisnis, Vol. 8, 150$165,1412-4467$.

Altaf, N. (2016). Economic value added or earnings: What explains market value in Indian firms? Future Business Journal, 2(2), 152-166. http://doi.org/10.1016/j.fbj.2016.11.001
Anshari, B. (2004). Analisis Hubungan Struktur Modal Dengan Economic Value Added ( EVA ) Guna Menilia Kinerja Perbankan ( Studi Kasus Saham Lima Bank Terbesar Berdasarkan Aset dan Modal di BEJ tahun 2003 - 2004 ), 1-9.

Arisanti, A., \& Bayangkara, I. (2016). Analisis perbandingan antara rasio keuangan dan metode economic value added sebagai pengukur kinerja keuangan perusahaan (Studi kasus pada perusahaan rokok yang terdaftar di bei periode tahun 2012 -2014. Jea17, 1(1), 97-108.

Brigham, E. dan J. F. H. (2001). Manajemen Keuangan II (Salemba Em). Jakarta.

Brigham, J. F. H. \& E. F. (2006). Dasar-Dasar Manajemen Keuangan. (A. A. Yulianto, Ed.) (10th ed.). Jakarta: PT. Salemba Empat.

Daru, M. U. (2016). Economic Value Added (EVA) as tool for Measuring Financial Performance, 6(9), 40-44.

Dintha, R., \& Surachim, A. (2016). Pengaruh Capital Structure Dan Working Capital Management, 1(1), 42-46.

Dwirachma, A., \& Imas, P. (2014). Pengaruh Struktur Modal Terhadap Nilai Perusahaan Asuransi Yang L I Sting Di Bursa Efek Indonesia, 2.

Fitriani, A., \& Purnamasari, I. (2015). Pengaruh Profitabilitas Terhadap Struktur Modal Pada Perusahaan Manufaktur Subsektor Logam Dan Sejenisnya Yang Terdaftar Di Bursa Efek Indonesia (Bei) Tahun 20112013.

Hafsah dan Sri Sutra Sari. (2015). Jurnal Riset Akuntansi Dan Bisnis Volume 15 No.1/ Maret 2015, 15(1), 52-64.

Kasmir. (2008). Analisis Laporan Keuangan. Jakarta: Raja Grafindo Parsada.

Kasmir. (2012). Analisis Laporan Keuangan,Edisi Pertama. Jakarta: Rajawali Pers.

Kaunang, C. A. S. (2013). Rasio Profitabilitas Dan Economic Value Added Pada Perusahaan Yang Tergabung Dalam LQ 45. Jurnal EMBA, 1(3), 648-658.

Khan. (2006). Is Economic Value Added more Associated with Stock Return than Accounting Earnings? The UK Evidence. International Journal of Managerial Finance, 2(4), 343-353. http://doi.org/10.1108/17439130610705526

Leepsa, N. M., \& Mishra, C. S. (2016). Performance of Acquirer in the Manufacturing Sector: Analysis of Economic Value Added in Different Industries of the Manufacturing Sector in India, XXXI(August 2016), 41-72. 
Lin, C., \& Zhilin, Q. (2008). What Influence the Company'S Economic Value Added? Empirical Evidence From China'S Securities Market. Management Science and Engineering, 2(1).

Muslimah, P. N., Purnamasari, I., \& Andari, R. (2016). PENGARUH LEVERAGE TERHADAP PERTUMBUHAN LABA Studi pada PT Krakatau Steel Tbk Tahun 2005-2014, (1203874).

Ningsih, S. dan. (2015). Jurnal Ilmu \& Riset Akuntansi Vol. 4 No. 11 (2015) Analisis PEngaruh Kinerja Keuangan dan Economic... - Ningsih, Susi Mujia, 4(11).

Niresh, J. A., \& Velnampy, T. (2014). Firm Size and Profitability: A Study of Listed Manufacturing Firms in Sri Lanka. International Journal of Business and Management, 9(4), 57-64. http://doi.org/10.5539/ijbm.v9n4p57

Nugraha, A. A. (2013). Analisis pengaruh struktur modal terhadap kinerja perusahaan yang tergabung dalam Indeks Kompas 100. Management Analysis Journal, 2(1), 1-7.

Purnamasari, I. (2009). kinerja keuangan perusahaan sangat ditentukan oleh sistem pengendalian manajemen yang terdiri dari struktur dan proses. Retrieved from http://ejournal.stiepena.ac.id/index.php/fe/ar ticle/view/49/46

Siddharta Utama. (1997). EVA Pengukur Penciptaan Nilai Perusahaan. Jakarta: Usahawan.

Suwito. (2002). Analisis Hubungan Struktur Modal dengan Economic Value Added (EVA) guna menilai kinerja perusahaan (Studi Kasus Industri Kertas di BEJ tahun 1994-2000)Master theses. Program Pasca Sarjana Universitas Diponegoro. 